\title{
Blended Learning between Team Games Tournament and Web-Based Module to Improve Students' Competency of Light Vehicle Programs
}

\author{
Robby Wijaya ${ }^{a, 1, *}$, Widiyanti ${ }^{a, 2}$, Syarif Suhartadi ${ }^{a, 3}$, Basyirun $^{\mathrm{b}, 4}$ \\ ${ }^{a}$ Department of Mechanical Engineering, State University of Malang, Malang Indonesia \\ ${ }^{\mathrm{b}}$ Universitas Negeri Semarang, Semarang, Indonesia \\ ${ }^{1}$ robbywijaya1206@gmail.com@ gmail.com; ${ }^{2}$ widiyanti.ft@um.ac.id; ${ }^{3}$ syarif.suhartadi.ft@um.ac.id; ${ }^{4}$ basyirun@mail.unnes.ac.id
}

\begin{tabular}{|c|c|}
\hline Article Info & " ABSTRACT \\
\hline $\begin{array}{l}\text { Article history: } \\
\text { Received: February 24, } 2019 \\
\text { Revised: March 14, } 2019 \\
\text { Accepted: March 28, } 2019\end{array}$ & $\begin{array}{l}\text { Education plays an important role in printing Human Resources (HR), including } \\
\text { vocational schools. Learning methods and the availability of learning resources becomes } \\
\text { very important and needed. The existence of the internet needs to be utilized to create } \\
\text { innovative and interesting learning. The research method used is Classroom Action } \\
\text { Research (CAR) which aims to determine the effect of the implementation of the blended } \\
\text { learning team games tournament (TGT) and the Web-Based Module as an Effort to } \\
\text { Increase the Achievement of Student Competencies in the Light Vehicle Engineering } \\
\text { Program. The study was conducted in class X TKR 1, SMKN } 1 \text { Singosari in the 2017- } \\
2018 \text { school year as many as } 32 \text { students. The treatment is given consisted of Action } 1 \\
\text { and Action } 2 \text { by observing the activities of the teacher, students, and post-test scores. In } \\
\text { the pre-action, the percentage of completeness obtained was } 67.74 \% \text { while the Minimum } \\
\text { Completeness Standard was } 75 \% \text {. After action } 1 \text {, the achievement of student competence } \\
\text { reached 93.5\% with an average value of 86.53. While in Action } 2 \text {, student learning } \\
\text { completeness was } 87.09 \% \text { with an average value of } 81.3 \text {. From the two actions } \\
\text { implemented, it is found that the average results are above the minimum standard of a } \\
\text { predetermined value of } 75 \text {. The application of blended learning can improve student } \\
\text { learning outcomes because the learning process is more interesting, active and } \\
\text { innovative. students are more enthusiastic and happy with the learning model. With the } \\
\text { tournament, students are trained to be responsible, care for friends, study independently } \\
\text { and compete healthily. The application of Blended Learning team games tournament } \\
\text { (TGT) and Web-based modules are recommended to be applied to other subjects } \\
\text { because it is proven to be able to increase the achievement of student competencies and } \\
\text { to be creative, innovative and interesting method. }\end{array}$ \\
\hline
\end{tabular}

\section{INTRODUCTION}

Education plays an important role in improving the quality of Human Resources (HR) [1], [2]. The most strategic improvement of human resources is through education. Because it is an effort and process of increasing human resources and educating the nation's life. One effort to improve human resources is through the learning process in schools. The success of educational programs through teaching and learning in schools is influenced by several factors such as students, curriculum, education personnel, costs, facilities, and infrastructure as well as environmental factors [3]-[5]. These factors must be adjusted to the eight national education standards contained in the Government Regulation No. 32 of 2013. If these factors are met, the teaching and learning process will run smoothly, thereby supporting the achievement of learning outcomes which will improve the quality of education. 
Change in the educational world is a challenge for all involved parties. Besides to the education system that needs to be renewed, a more innovative learning process needs to be developed to achieve the competencies of students. The learning process with the old paradigm must be changed with a new paradigm that can increase student creativity in thinking, the direction of learning is not only one way so that the teaching and learning process will be able to increase collaboration between students and teachers, students and students, as well as with unconventional learning models but with innovations so students better understand the material presented.

Besides to the application of learning models that are still static, the availability of learning resources in vocational education is also still limited. The forms of learning resources available such as books, handouts need to be developed along with technological advancements. The availability of the internet needs to be utilized to support the learning process, especially as a provider of learning resources. Advances in information and communication technology need to be utilized in positive terms. E-learning is a model that utilizes the current availability of the internet. By providing learning resources that are integrated through the internet, it will be very possible for students to access all available material without being limited by space and time. Especially at this time, the majority of students have smartphones that can be utilized all of its features to support the teaching and learning process.

Based on the results of preliminary observations at VHS 1 Singosari, there were several teachers and student problems. The teaching and learning process especially theory runs statically and tends to be teacher-centered. The lecture model is carried out using the LCD Projector that displays the material presented. The availability of learning resources is very limited, both in quality and quantity. Books as a learning resource are only owned by the teacher, and student learning resources only through the material presented and also the task of making papers obtained from the internet and are not organized. The paperwork is done in groups and based on interviews with students, it only done by certain students. With these conditions, the results of students' ability to understand the material are not evenly distributed. Inequality in achieving competence is evidenced through the results of daily tests of students who can achieve the Minimum completeness Criteria 75 only 15 students out of 31 students or $48.38 \%$ in the class.

From the facts obtained in grade $\mathrm{X}$ automotive basic subjects, the findings are limited availability of learning resources and the dominance of active students in class, both when learning theory and practice. Research will be conducted by trying to integrate learning (blended learning) use Webbased learning module with the Teams Games Tournament (TGT) type of cooperative learning method. The use of Webbased learning modules is expected to meet the needs of student learning resources organized by teachers [6]. The use of this Web-based learning model can also train students to get accustomed to learning and working on problems through a computer. Thus, the use of Web-based learning modules will sync and support the current model of education evaluation in Indonesia.
Besides of the use of Web-based learning modules, then, the material will be developed by the cooperative learning method namely Teams Games Tournament (TGT) which has not been previously applied. There are advantages of the TGT model of cooperative learning [7], [8], namely (1) the involvement of students in high learning, (2) students became enthusiastic in learning, (3) the knowledge obtained by students was not solely from the teacher but through instruction by students themselves, and (4) can foster positive attitudes in students such as cooperation tolerance, can accept the opinions of others, and others.

TGT has several components [9], namely: (1) class presentations, (2) teams, (3) games, (4) tournaments, and (5) team recognition. The group and game elements make all students can be actively involved in learning. The elements of the game can also present a dimension of excitement that creates a pleasant learning atmosphere. The tournament element in TGT can present a competitive situation so that students' motivation will be motivated to do their best or devote all their potential to win the competition at the tournament table and deliver their group to be winners. The group that gets the highest score will get an award (reward) from the teacher, so the winning group and the other groups will be more motivated to learn so they can win the next tournament.

Based on this background, it is expected to increase the achievement of student competencies through student activeness and learning independence created through appropriate cooperative learning methods.

\section{METHOD}

The Classroom Action Research (CAR) was carried out in 2 cycles consisting of 4 stages namely planning, implementing actions, observing and reflecting. In this study the presence of researchers as participant observers. Researchers as data collection designers, data analyzers, interpreters to reporters of the results. As for the implementation phase, the researcher acts as an assistant of the subject teacher to help deliver the material to fit the plan that was prepared earlier.

The study was conducted at VHS 1 Singosari Jl. Raya Mondoroko No. 3 Malang Regency within a period of 6 weeks starting from March 2 to April 6, 2018. The implementation of cycle 1 and 2 was carried out in the even semester of the 20172018 school year. The subjects in this study were students of class X TKR 1, involving 31 students. This study uses instruments in the form of teacher active observation sheets, student activeness, and field notes. Data collection techniques include observation documentation, and also learning achievement tests. Data analysis was performed by comparing the measured data during pre-action, cycle 1 , cycle 2 to determine the effect of the implementation of the Blended Learning Team Games Tournament (TGT) and Web-Based Modules on achieving student competency. Data analyzed were test results, teacher activities, and student activities.

\section{A. Teacher and Student Activities}

Teacher and student activities are observed with an observation sheet of teacher and student activities that contain indicators of activity and implementation of learning as planned. The assessment of this observation sheet is to 
determine the percentage of teacher and student activities. Presentation of Activity (PA) for teachers and students is obtained by the formula:

$$
P A=\frac{\text { fulfilled indicator }}{\text { total indicator }} \times 100 \%
$$

TABLE I. TEACHER AND STUDENT ACTIVITY CRITERIA

\begin{tabular}{ll}
\hline \multicolumn{1}{c}{ Percentage } & Category \\
\hline $75 \%<$ score $\leq 100 \%$ & Excellent \\
$50 \%<$ score $\leq 75 \%$ & Good \\
$25 \%<$ score $\leq 50 \%$ & Moderate \\
$0 \%<$ score $\leq 25 \%$ & Less \\
\hline
\end{tabular}

The assessment indicators that must be fulfilled by the teacher and students are divided into six stages, including opening, class presentations, group discussions, and tournaments, group awards, and closing.

\section{B. Student Learning Outcomes}

Student learning outcomes are analyzed based on the level of cognitive understanding which includes aspects of knowledge, understanding, application and evaluation. Student cognitive results are determined from the acquisition scores from the results of the test questions in each cycle. Calculation of Cognitive Score (SK) for each student uses the following formula:

$$
S K=\frac{\text { Students'score }^{\prime}}{\text { Maximum score }} X 100 \%
$$

\begin{tabular}{|c|c|}
\hline Percentage & Category \\
\hline $81-100$ & Excellent \\
\hline $61-80$ & Good \\
\hline $41-60$ & Moderate \\
\hline $21-40$ & Less good \\
\hline $00-20$ & Poor \\
\hline
\end{tabular}

TABLE II. LEARNING OUTCOMES LEVEL CRITERIA

The criterion for the success of this study is that if a minimum of $75 \%$ of students are active. Students are said to be active if the percentage of student activeness $>75 \%$. In addition, if the average student learning outcomes are higher than the average student learning outcomes on the previous test and at least $75 \%$ of students reach the minimum score of 75 .

Achievement of competence can be seen from the learning outcomes of students of class X TKR 1 VHS 1 Singosari at the time of pre-action carried out through pre-test only amounting to $67.74 \%$ and there are several students with low academic ability, and less active in class. After applying the TGT blended learning and web-based modules, student learning outcomes have improved. Improved learning outcomes from pre-action, action 1 , action 2 are presented in the Table 3 .

TABLE III. LEARNING OUTCOMES IMPROVEMENT

\begin{tabular}{lll}
\hline & \multicolumn{1}{c}{ Percentage } & \multicolumn{1}{c}{ Improvement } \\
\hline Pre-treatment & $67,74 \%$ & \\
Treatment 1 & $93,5 \%$ & $25,76 \%$ \\
Treatment 2 & $87,09 \%$ & $-6,4 \%$ \\
\hline
\end{tabular}

The implementation of TGT and the Web-based module have been able to significantly improve student learning outcomes by $25.76 \%$. With a very good category. There was a decline of $6.4 \%$ from action 1 to action 2 due to factors that could not be controlled by the researchers including 6 students who were licensed at the time of the study because it coincided with a sudden assignment given by the school, while at the time of taking the scores of 6 students present, so there is a value gap. The percentage of students completeness can be seen in the Figure 1.

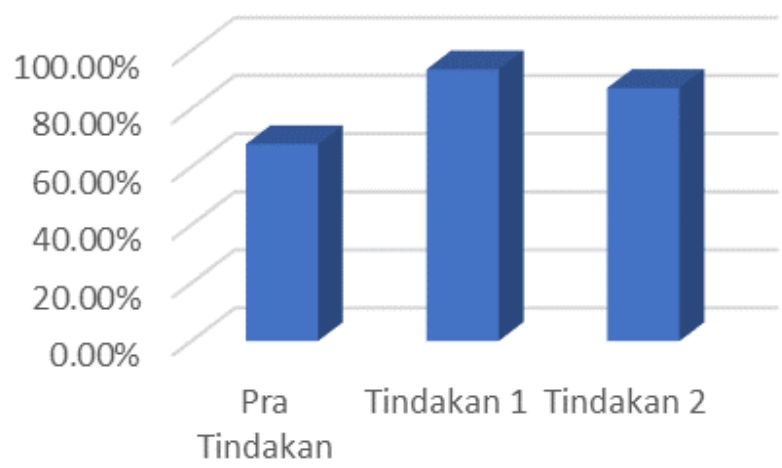

Fig. 1. Learning outcomes improvement

Student learning outcomes are also inseparable from the activities of the teacher and also students. before applying blended learning teacher activity is not too high at $65.27 \%$, while student learning activities are relatively low at $50.63 \%$. The activities of the teacher and also students increase after being given an explanation by the researcher and carry out learning in accordance with the learning plan. Student and teacher learning activities ranging from pre-action, action 1 and action 2 are presented in the Table 4 .

\begin{tabular}{lcc} 
TABLE IV. & TEACHER AND STUDENT ACTIVITIES IMPROVEMENT \\
\hline & $\begin{array}{c}\text { Teacher's } \\
\text { Activity }\end{array}$ & $\begin{array}{c}\text { Student's } \\
\text { Activity }\end{array}$ \\
\hline & $65,27 \%$ & $50,63 \%$ \\
Pre-treatment & $84,72 \%$ & $83,97 \%$ \\
Treatment 1 & $88,48 \%$ & $90,3 \%$ \\
Treatment 2 & &
\end{tabular}

The implementation of blended learning can increase teacher activity and also learning activities of class X TKR 1 . Teacher activity increased by $19.45 \%$ from pre-action to action 1 and an increase of $3.72 \%$ from action 1 to action 2 with "very good" criteria. The increase in student activity by $33.34 \%$ from pre-action to action 1, and an increase of $6.33 \%$ from action 1 to action 2 with the criteria "very good". Increased teacher and student activities are presented in the Figure 2. 


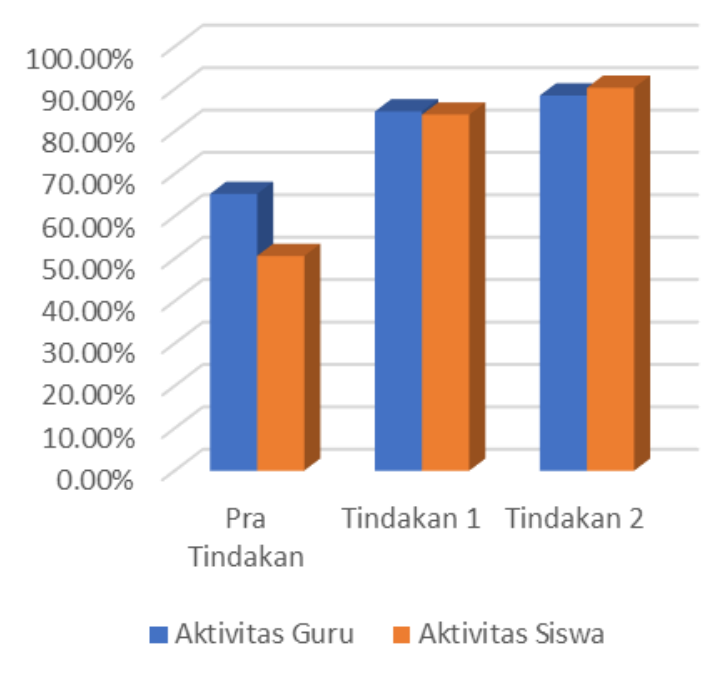

Fig. 2. Improvement of teachers and students' activity

TGT cooperative learning is consists of five stages. The stages of Cooperative Learning type Team Games Tournament (TGT) include: (1) class presentations, (2) teams, (3) games, (4) tournaments, and (5) group awards.

Blended learning between TGT and Web-based modules can improve student learning competency because in TGT, students not only receive material passively from the teacher but also actively participate in the learning process starting from independent learning through modules, questions and answers, group discussions, where each group members exchange ideas and help. In addition, academic games such as tournaments and quizzes and prizes that are applied increasingly add to the enthusiasm of students to study harder.

To induce student learning activities, the teacher can carry out the following behaviors: 1) using multi methods and multimedia, 2) giving assignments individually and in groups, 3) giving opportunities for students to carry out experiments in small groups, 4) provide assignments to read learning materials, note things that are unclear, and 5) hold questions and answers and discussion. This can increase the interest and activeness to attend Automotive Basic Engineering learning. Besides, students also do not feel bored and bored because of variations in the implementation of learning.

Based on the data exposure of the results of the study, the results of the Action 1 show the average student score is $93.5 \%$. When compared with the results of the previous pretest with the percentage of completeness reaching $67.74 \%$, action 1 has experienced a good improvement. The average student in action 1 is 86.53 with the highest score of 100 and the lowest score of 67.5. The average score is more than minimum criteria score which is equal to 80 . It is felt that there are still some things that need to be improved and also evaluated, so it continued to the action 2 .

Action 2 is implemented even better which can be seen from the results of observations of student learning activities and teaching activities that have fulfilled the classification with the category of "very good". The percentage of students completeness reached $87.09 \%$ with an average score of 81.29 with the highest score of 95 and the lowest of 67.5. When compared with action 1 , there was a slight decrease in average student completeness. based on researchers' observations, this is because the material is new to students and the number of study hours is too short. However, the achievement of student competencies is still said to be increasing and has exceeded the minimum criteria score of 80 . Related previous research also shows a good impact of TGT cooperative learning implementation in a learning process [10]-[12].

Based on the results that have been achieved during the implementation of the TGT blended learning and the Webbased Module, students experience increased intelligence and learning competence. The cooperative learning can also improve student performance in academic tasks and able to helping students grow critical thinking skills.

Every activity is bound to encounter obstacles even though it has been designed as well as possible. Even though the implementation of the research is in accordance with the stages of the spiral model class action research and also the stages of the TGT there are still obstacles to be faced. These obstacles are experienced during learning in Action 1 and 2 which will be an improvement for further research. Table 5 shows the obstacles that faced during the research. Based on the Table 5, it can be used as a lesson for future researchers so that it does not reoccur in the application of blended learning that combines cooperative learning type team games tournament (TGT) and web-based modules.

\section{TABLE V. OBSTACLES DURING THE RESEARCH}

\begin{tabular}{|c|c|c|c|}
\hline \multicolumn{2}{|r|}{ Problem } & \multicolumn{2}{|r|}{ Solution } \\
\hline 1 & $\begin{array}{l}\text { The use of the Web is new to } \\
\text { students so it requires a } \\
\text { relatively long time to explain }\end{array}$ & 1 & $\begin{array}{l}\text { Must be done often so students } \\
\text { get used to it }\end{array}$ \\
\hline 2 & $\begin{array}{l}\text { Limited internet access for } \\
\text { some provider }\end{array}$ & 2 & $\begin{array}{l}\text { All students use the same well- } \\
\text { internet access provider }\end{array}$ \\
\hline 3 & $\begin{array}{l}\text { Some cheating due to high } \\
\text { team ambition }\end{array}$ & 3 & $\begin{array}{l}\text { The teacher explains that victory } \\
\text { is not everything, the most } \\
\text { important thing is how to } \\
\text { improve the quality of the group } \\
\text { by learning harder. }\end{array}$ \\
\hline 4 & $\begin{array}{l}\text { There are several students } \\
\text { who have difficulty due to } \\
\text { their low academic ability }\end{array}$ & 4 & $\begin{array}{l}\text { Keep encourage and motivate so } \\
\text { that students do not feel inferior } \\
\text { and miss lessons }\end{array}$ \\
\hline 5 & $\begin{array}{l}\text { Action } 2 \text { cannot be maximal } \\
\text { because it coincides with } \\
\text { other schedules in the school }\end{array}$ & 5 & $\begin{array}{l}\text { Ask for students to keep studying } \\
\text { at home and asking group friends } \\
\text { related material }\end{array}$ \\
\hline
\end{tabular}

\section{CONCLUSION}

Based on the results of research and discussion, it can be concluded that the implementation of Blended Learning Team Games Tournament (TGT) and Web-Based Modules is able to increasing learning activities. Students can also improve their competencies achievement.

It is recommended to implement blended learning cooperative learning type Team Games Tournament (TGT) and Web-based modules which have been proven to be able to improve student activity and achievement. In addition, the use 
of technology should also be applied so that learning is more varied and innovative so that it is preferred by students. smartphones are no longer prohibited for use in the classroom, as long as they are used properly and correctly. Learning is no longer limited in the classroom, but can also be done in various places and times.

\section{References}

[1] A. Kayahan Karakul, "Educating labour force for a green economy and renewable energy jobs in Turkey: A quantitave approach," Renew. Sustain. Energy Rev., vol. 63, pp. 568-578, 2016.

[2] M. Hashim and F. Hameed, "Human resource management in $21 \mathrm{st}$ century: issues \& challenges \& possible solutions to attain competitiveness," Int. J. Acad. Res. Bus. Soc. Sci., vol. 2, no. 9, p. 44, 2012.

[3] G. Chen and J. Zhang, "A case study of factors influencing the learning of engineering students," World Trans. Eng. Technol. Educ., vol. 12, no. 2, pp. 176-180, 2014.

[4] F. J. Tasiam, D. Kustono, P. Purnomo, and H. Elmunsyah, "Fostering pedagogic competence of electrical engineering vocational high school teacher in facing ASEAN economic community," Eur. J. Educ. Stud., vol. 3, no. 8, pp. 558-571, 2017.

[5] H. Kauffman, "A review of predictive factors of student success in and satisfaction with online learning," Res. Learn. Technol., vol. 23, 2015.

[6] B. Hariadi and T. Wurijanto, "Influence of Web Based Cooperative Learning Strategy and Achiever Motivation on Student Study Outcome," Int. J. Eval. Res. Educ., vol. 5, no. 3, pp. 189-199, 2016.

[7] R. A. Aulyawati and A. A. Sujadi, "Implementasi Pembelajaran Kooperatif Tipe TGT (Teams Games Tournament) Untuk Meningkatkan Minat dan Prestasi Belajar Matematika Siswa Kelas VIII C SMPN 2 Sanden Bantul," UNION J. Ilm. Pendidik. Mat., vol. 4, no. 3, pp. 419426, 2016.

[8] R. Rahmawati, "Improving English speaking ability using the TeamGames-Tournament technique," English Educ. J., vol. 8, no. 1, pp. 1-13, 2017.

[9] R. E. Slavin, Cooperative Learning; theory, research, and practice, Second edi. Massachusetts: Allyn \& Bacon, 2010.

[10] A. Veloo and S. Chairhany, "Fostering students' attitudes and achievement in probability using teams-games-tournaments," ProcediaSocial Behav. Sci., vol. 93, pp. 59-64, 2013.

[11] M. M. V. Wyk, "The effects of Teams-Games-Tournaments on achievement, retention, and attitudes of economics education students," J. Soc. Sci., vol. 26, no. 3, pp. 183-193, 2011.

[12] A. Salam, A. Hossain, and S. Rahman, "Effects of Using Teams Games Tournaments (TGT) Cooperative Technique for Learning Mathematics in Secondary Schools of Bangladesh," Malaysian Online J. Educ. Technol., vol. 3, no. 3, pp. 35-45, 2015. 